\title{
Effects of phytase supplementation on growth performance, slaughter performance, growth of internal organs and small intestine, and serum biochemical parameters of broilers
}

\author{
Wei Wang, Zhiyue Wang, Haiming Yang*, Yujuan Cao, Xiaochun Zhu, Yang Zhao \\ College of Animal Science and Technology, Yangzhou University, Yangzhou, China; ${ }^{*}$ Corresponding Author: yhmdlp@qq.com \\ Received 9 April 2013; revised 30 May 2013; accepted 12 June 2013 \\ Copyright (C) 2013 Wei Wang et al. This is an open access article distributed under the Creative Commons Attribution License, which \\ permits unrestricted use, distribution, and reproduction in any medium, provided the original work is properly cited.
}

\begin{abstract}
The objective of this study was to investigate the effects of phytase supplementation on growth performance, slaughter performance, growth of internal organs and small intestine, and serum biochemical indices of broilers. A total of 360 1-day-old Ross 308 broilers were randomly divided into 4 groups with 3 replicates and 30 broilers per replicate (15 male, 15 female). The treatments were fed with basal diet supplemented with $0 \%, 0.01 \%, 0.02 \%$ and $0.03 \%$ phytase. The results showed that: 1) Phytase supplementation increased the body weight gain and the body weight of Ross 308 broilers ( $P<$ 0.05); 2) Compared with the control group, the feed containing $0.02 \%$ phytase increased the eviscerated carcass ration $(P<0.05)$; 3 ) The feed supplemented phytase could improve the weight of liver $(P<0.05)$; 4) The phytase supplementation was good for the weight and the length of small intestine; 5) The phytase supplementation which improved the serum phosphorus $(P)$ consistency and lowered serum calcium (Ca) consistency was $0.02 \%$. According to the above analysis, the feasible supplementation of phytase (enzyme activity for $5000 \mathrm{u} / \mathrm{g}$ ) in broiler dietary was $0.02 \%$.
\end{abstract}

Keywords: Phytase; Performance; Internal Organs; Small Intestine; Serum Biochemical Parameters

\section{INTRODUCTION}

Corn-soybean diets are rich in phytic acid which is not available for non-ruminant animals. Most of phytate phosphorus is discharged along with excrement. In this case, it not only leads to waste of resource, but also increases the environmental pollution. As a new type of feed additive, phytase can improve the decomposition rate of phytic acid and its salt and release the phosphorus. At the same time, phytase can degrade complex of phytic acid salt and protein. So phytase can increase the nutriation value of the plant feed and decompose the chelate of phytic acid salt and trace element [1-3].

According to Simons et al. [4], techniques have been developed to produce microbial phytase for the diets of simple-stomached animals and improve the efficiency of phytase-P. The availability phosphorus is increased to over $60 \%$ and the amount of $\mathrm{P}$ in the dropping is decreased $50 \%$ when microbial phytase is added to low-P diets for broilers. Compared with broilers which diets do not supplement phytase, the growth rate and feed conversion ratio are improved with the low-P diets containing microbial phytase. Nagata et al. [5] has reported that phytase can improve the growth performance and nutrient utilization of broilers.

This study was conducted to evaluate the effects of phytase supplementation on growth performance, slaughter performance, growth of internal organs and small intestine, and serum biochemical parameters of Ross 308, then determine the feasible addition of phytase in the diets of broilers for optimizing the feed formula and reducing the production cost.

\section{MATERIALS AND METHODS}

\subsection{Materials and the Site of Experiment}

The activity of phytase is $5000 \mathrm{u} / \mathrm{g}$. There are not phytase, calcium and phosphorus in the vitamin-mineral premix. The experiment was conducted at the pasture of Yangzhou University, Yangzhou, China. 


\subsection{Experiment Design and the Diet of Broilers}

The treatments were fed with basal diet supplemented with $0 \%, 0.01 \%, 0.02 \%$ and $0.03 \%$ phytase, and were set to $\mathrm{A}, \mathrm{B}, \mathrm{C}$ and $\mathrm{D}$ respectively. A total of 360 1-day-old Ross 308 broilers were randomly divided into 4 groups with 3 replicates and 30 broilers per replication (15 male, 15 female). Chicks were given a free choice access to diets and tap water for 42 days. The chicks were fed the experimental diets throughout the experimental period. There are three phases, 0 to 10,11 to 24 and 25 to 42 days of age. Broilers were weighted by pen at $0,7,14$, $21,28,35$ and 42 days of age. Weight gain was determined as difference between initial weight and final weight. Feed intake was estimated by the difference between feed and leftovers. Feed conversion ratio was the relationship between feed intake and weight gain of birds in each experimental unit. The gross composition and mineral composition of the experimental diets are shown in Table 1.

\subsection{Analysis of Biochemical Indicator}

At the 42 days of age, 6 chickens ( 3 male and 3 female) randomly were taken out from every replicate to draw blood from wing venous. The blood was offcentered 10

Table 1. Ingredient composition of the control experimental diet to test broilers.

\begin{tabular}{|c|c|c|c|}
\hline Ingredients & 0 to $10 \mathrm{~d}$ & 11 to $24 \mathrm{~d}$ & 25 to $42 \mathrm{~d}$ \\
\hline Corn & 60.7 & 65.4 & 69.3 \\
\hline Soybean meal & 28.9 & 24.3 & 20.3 \\
\hline Corn protein meal & 7 & 5 & 5 \\
\hline Vitamin-mineral premix 1 & 1.0 & 1.0 & 1.0 \\
\hline Calcium phosphate secondary & 0.4 & 0.4 & 0.4 \\
\hline Limestone & 2.0 & 1.9 & 1.8 \\
\hline Soybean oil & - & 2.0 & 2.2 \\
\hline Total & 100 & 100 & 100 \\
\hline \multicolumn{4}{|c|}{ Calculated value } \\
\hline $\mathrm{ME}(\mathrm{MJ} / \mathrm{Kg})$ & 12.59 & 13.14 & 13.31 \\
\hline Crude protein $(\%)$ & 22.98 & 19.98 & 18.46 \\
\hline $\mathrm{Ca}(\%)$ & 0.91 & 0.86 & 0.81 \\
\hline $\mathrm{P}(\%)$ & 0.45 & 0.42 & 0.41 \\
\hline
\end{tabular}

Containing by $\mathrm{kg}$ of diets: manganese, $10,000 \mathrm{mg}$; zinc, $7500 \mathrm{mg}$; copper, $800 \mathrm{mg}$; iron, $10,000 \mathrm{mg}$; iodine, $45 \mathrm{mg}$; selenium, $44.7 \mathrm{mg}$; vitamin A, 1 100,000 IU; vitamin D, 3,360,000 IU; vitamin E, 3600 IU; vitamin K, 3260 $\mathrm{mg}$; thiamine hydrochloride, $260 \mathrm{mg}$; riboflavin, $960 \mathrm{mg}$; DL, calcium pantothenate, $1300 \mathrm{mg}$; nicotinic acid, $8000 \mathrm{mg}$; sinkaline, 66,000 mg; vitamin B1, $22.7 \mathrm{mg}$; folic acid, $120 \mathrm{mg}$; pyridoxine hydrochloride, $530 \mathrm{mg}$; biotin, $24 \mathrm{mg}$. minutes at $4500 \mathrm{r} / \mathrm{min}$ and got serum for measuring the serum biochemical index. Serum levels of $\mathrm{Ca}, \mathrm{P}$, alkaline phosphatase (ALP), albumin (ALB), total protein (TP) and urea nitrogen (BUN) were measured by using the automatic biochemical analyzer of beckman coulter of unicel D $\times$ C 800 and serum level of growth hormone (GH) was measured by using the radiation immune instrument of $\gamma-911$.

\subsection{Mensuration of Slaughter Performance, Internal Organs and Small Intestine}

At the 42 days of age, 6 chickens ( 3 male and 3 female) were killed by cervical dislocation, which were taken out randomly from each cage and starved overnight. Then, the weight of birds and their organs were harvested. Organs analyses included heart, liver, spleen, duodenum, jejunum, ileum, cecum and rectum weights and duodenum, jejunum and ileum lengths. The ileum was defined as the region from Meckel's diverticulum to a point 40 $\mathrm{mm}$ proximal to the ileocecal junction. The jejunum was defined was the portion of intestine extending from the bile duct enterance to Meckel's diverticulum.

\subsection{Data Analyses}

All data were recorded on a weekly basis and statistically analyses were performed using SPSS 17.0 for windows. The data was analysed by analysis of variance (ANOVE). The differences between group means were separated by LSD multiple range test. In all instances, differences were reported as significant at $\mathrm{P}<0.05$.

\section{RESULT AND DISCUSSION}

\subsection{Effects of Phytase Addition on Growth Performance of Broilers}

The results of growth performance of broilers are presented in Tables 2 and 3. Compared with the control group broilers, the diet supplemented phytase improved the weight of broilers $(\mathrm{P}<0.05)$. From 1 -week to 3-weeks, there was no significant difference among group $\mathrm{B}, \mathrm{C}$ and $\mathrm{D}$ broilers $(\mathrm{P}>0.05)$. However, from 4-weeks to 6-weeks, the weight of group $\mathrm{C}$ and $\mathrm{D}$ broilers were higher than that of group B broilers $(\mathrm{P}<0.05)$, but there was no significant difference between group $\mathrm{C}$ and $\mathrm{D}$ broilers $(\mathrm{P}>0.05)$. Compared with the control group broilers, the weight of group $\mathrm{C}$ broilers were increased by $22.64 \%$ ( $\mathrm{P}<0.05), 24.47 \%(\mathrm{P}<0.05)$, $23.62 \%(\mathrm{P}<0.05)$ in weeks of 4,5 and 6 , respectively. So, we concluded that the diets supplemented phytase increased the weight of broilers.

At 42 days of age, the order of daily gain and final weight were both $\mathrm{C}>\mathrm{D}>\mathrm{B}>\mathrm{A}$. Results showed no significant difference between group $\mathrm{C}$ and $\mathrm{D}$ broilers on 
Table 2. Effects of phytase supplementation on weight of broilers (g).

\begin{tabular}{|c|c|c|c|c|}
\hline Attribute & Group A & Group B & Group C & Group D \\
\hline $0 \mathrm{w}$ & $43.33 \pm 4.35$ & $43.04 \pm 4.11$ & $43.38 \pm 4.30$ & $43.14 \pm 5.15$ \\
\hline $1 \mathrm{w}$ & $129.06 \pm 1.68^{\mathrm{a}}$ & $138.17 \pm 2.02^{\mathrm{b}}$ & $140.00 \pm 2.50^{\mathrm{b}}$ & $139.74 \pm 2.87^{b}$ \\
\hline $2 \mathrm{w}$ & $300.61 \pm 16.80^{\mathrm{a}}$ & $344.58 \pm 29.13^{b}$ & $356.10 \pm 3.15^{\mathrm{b}}$ & $352.90 \pm 13.06^{\mathrm{b}}$ \\
\hline $3 \mathrm{w}$ & $556.33 \pm 9.29^{\mathrm{a}}$ & $665.00 \pm 15.87^{b}$ & $686.44 \pm 2.88^{\mathrm{b}}$ & $681.67 \pm 27.06^{b}$ \\
\hline $4 w$ & $897.97 \pm 18.82^{\mathrm{a}}$ & $1023.82 \pm 17.03^{\mathrm{b}}$ & $1101.23 \pm 18.54^{\mathrm{c}}$ & $1111.00 \pm 24.88^{\mathrm{c}}$ \\
\hline $5 \mathrm{w}$ & $1237.22 \pm 35.30^{\mathrm{a}}$ & $1416.01 \pm 41.63^{\mathrm{b}}$ & $1540.00 \pm 29.31^{\mathrm{c}}$ & $1550.75 \pm 26.87^{c}$ \\
\hline $6 w$ & $1674.10 \pm 27.78^{\mathrm{a}}$ & $1924.15 \pm 33.31^{\mathrm{b}}$ & $2069.45 \pm 24.15^{\mathrm{c}}$ & $2054.05 \pm 22.01^{\mathrm{c}}$ \\
\hline
\end{tabular}

$\overline{\mathrm{a}, \mathrm{b}, \mathrm{c}}$ Means within a row with different superscript are significantly different $(\mathrm{P}<0.05)$.

Table 3. Effects of phytase supplementation on growth performance of broilers.

\begin{tabular}{ccccr}
\hline Attribute & Group A & Group B & Group C & Group D \\
\hline Initial Weight (g) & $43.33 \pm 4.35$ & $43.04 \pm 4.11$ & $43.38 \pm 4.30$ & $43.14 \pm 5.15$ \\
Final Weight (g) & $1674.10 \pm 27.78^{\mathrm{a}}$ & $1924.15 \pm 33.31^{\mathrm{b}}$ & $2069.45 \pm 24.15^{\mathrm{c}}$ & $2054.05 \pm 22.01^{\mathrm{c}}$ \\
Daily Feed Intake (g) & $72.20 \pm 10.91$ & $77.05 \pm 1.42$ & $83.27 \pm 3.59$ & $81.47 \pm 4.70$ \\
Daily Gain (g) & $38.83 \pm 0.66^{\mathrm{a}}$ & $44.79 \pm 0.79^{\mathrm{b}}$ & $48.24 \pm 0.23^{\mathrm{c}}$ & $47.88 \pm 0.23^{\mathrm{c}}$ \\
Feed Conversion Ratio & $1.86 \pm 0.25$ & $1.72 \pm 0.00$ & $1.73 \pm 0.08$ & $1.70 \pm 0.10$ \\
\hline
\end{tabular}

${ }^{a, b, c}$ Means within a row with different superscript are significantly different $(\mathrm{P}<0.05)$.

the daily gain and final weight $(\mathrm{P}>0.05)$. However, the daily gain and final weight of group $\mathrm{C}$ broilers were higher than that of group A and B broilers $(\mathrm{P}<0.05)$. Compared with control group broilers, the daily gain and final weight of group $\mathrm{C}$ broilers were increased by $24.23 \%(\mathrm{P}<0.05)$ and $23.62 \%(\mathrm{P}<0.05)$ respectively. Group B, C and D broilers were all lower than that of group A broilers on feed conversion ratio. And group B, $\mathrm{C}$ and $\mathrm{D}$ broilers were higher than that of group A broilers on daily feed gain. However, there was no significant difference among four groups of broilers on feed conversion ratio and daily feed gain $(\mathrm{P}>0.05)$. It implied that the diets supplemented phytase could improve the growth performance of broilers.

As seen in this study, the growth performance was improved. This result was in agreement with Lan et al. [6]. Results showed that the diets supplemented phytase did not affect the weight of broilers from 1-week to 3-week. The quantity of feed intake of broilers was low that might be the reason that caused it. From 4-week to 6-week, results are consistent with those found by Sun Hongxuan et al. [7], who dealt with broilers under the same conditions. Qi Guangzhou [8] reported that serum calcium decreased at the later of growth stage and it was possible to influence the function of phytase. On the other hand, Chen Qinghua [9] found that the function of phytase had something to do with the rate of calcium and phosphorus and the rate of $1: 1$ to $1.4: 1$ was the best. The function of phytase did not increase because the addition of phytase was $0.02 \%$ meted the needs of zymolyte.

At the 42 days of age, similar results were obtained by Sun Hongxuan et al. [7] who reported that high doses of microbial phytase improved the average daily gain of broilers. Nagata et al. [10] reported that the protein and energy levels in diets containing phytase influenced feed intake, weight gain and feed conversion rate of the broilers. It has been shown that phytase could improve the availability of phytate $\mathrm{P}$, total $\mathrm{P}$, some other minerals and amino acids. Rutherfurd et al. [11], using a low-phosphorus corn-soybean meal diet, reported that the inclusion of a novel microbial phytase into diet greatly increased ileal phytase $\mathrm{P}$ and total $\mathrm{P}$ absorption and ileal threonine, tyrosine, and histidine. Lelis et al. [12] reported that the diets containing phytase could release protein, energy, amino acid and digestive enzymes which were chelated with phytic acid. These reasons might improve the growth performance of broilers. According to the above results, the best addition of phytase supplementation in the diets was $0.02 \%$.

\subsection{Effects of Phytase Addition on Slaughter Performance of Broilers}

The results of slaughter performance of broilers are 
presented in Table 4. The results showed that the eviscerated carcass ratio of group $\mathrm{C}$ broilers was higher than that of control group broilers $(\mathrm{P}<0.05)$. However, there was no significant difference among group B, C, D broilers $(\mathrm{P}>0.05)$. The leg muscle ratio of group $\mathrm{D}$ broilers was higher than that of group $\mathrm{A}$ and $\mathrm{B}$ broilers $(\mathrm{P}$ $<0.05$ ), but, there was no significant difference between group $\mathrm{C}$ and $\mathrm{D}$ broilers $(\mathrm{P}>0.05)$. What's more, breast muscle ratio and abdominal fat ratio of broilers had no significant difference among four group broilers $(\mathrm{P}>$ $0.05)$.

Chisato et al. [13] reported that chicks receiving diets with phytase showed greater weight gain, feed intake feed efficiency, energy, $\mathrm{P}$ and nitrogen. In this experiment, the diets supplemented phytase of broilers could improve the eviscerated carcass ration and leg muscle ration. It was possible that phytase was effective to eviscerate ration carcass ration and leg muscle ration. But, phytase could not affect breast muscle ration and abdominal fat ration of treatments. For example, the addition of phytase to low-P diet didn't affect the abdominal fat ration of chicks by Yonemochi et al. [14].

\subsection{Effects of Phytase Addition on Growth of Internal Organs of Broilers}

The results of the growth of internal organs of broilers are shown in Table 5. The weight of liver of chicks which were fed the diets supplemented phytase exhibited significantly higher than that of control group broilers ( $\mathrm{P}$ $<0.05)$ and there was no significant difference among experimental group broilers $(\mathrm{P}>0.05)$. The weight of spleen of group D broilers was higher than that of group $\mathrm{A}, \mathrm{B}, \mathrm{C}$ broilers $(\mathrm{P}<0.05)$ and there was no significant difference among experimental group broilers $(\mathrm{P}>0.05)$. What's more, phytase supplementation did not affect the weight of heart $(\mathrm{P}>0.05)$.

In this current study, the research with the addition of phytase to low-P diets was the most [15-17]. The experiment could improve the weight of liver and spleen. However, Akyurke et al. [15] reported that the addition of phytase to low-P diet of corn-soybean meal did not improve the weight of heart, liver and spleen. Attia et al. [16] conducted the experiment that using the diet supplemented phytase $(500 \mathrm{FTU} / \mathrm{kg})$ to adjust the available $\mathrm{P}$ and $\mathrm{Ca}$ percentage according to BASF and got the similar result. Compared with negative control (containing $0.25 \%$ NPP), Akyurke et al. [17] found that the diet of negative control supplemented phytase could improve the weight of heart.

\subsection{Effects of Phytase Addition on Growth of Small Intestine of Broilers}

The results of the growth of small intestine of broilers intestine are shown in Table 6. The treatments had no effect $(\mathrm{P}>0.05)$ on the length of duodenum and ileum and the weight of ileum and cecum. The length of jejunum of group A broilers was higher than that of group B broilers $(\mathrm{P}<0.05)$ and there was no significant difference among group A, C and D broilers ( $\mathrm{P}>0.05)$. Phytase supplementation increased the weight of jejunum and rectum $(\mathrm{P}<0.05)$, but there was no significant difference $(\mathrm{P}>0.05)$ among experimental group broilers. In addition, the weight of duodenum of group $\mathrm{C}$ broilers was higher than that of group $\mathrm{A}$ and $\mathrm{D}$ broilers $(\mathrm{P}<$ $0.05)$.

There were several studies which indicate results that

Table 4. Effects of phytase supplementation on slaughter performance of broilers.

\begin{tabular}{cccc}
\hline Attribute & Group A & Group B & Group C \\
\hline Eviscerated carcass ration (\%) & $69.43 \pm 2.22^{\mathrm{a}}$ & $69.75 \pm 2.42^{\mathrm{a}, \mathrm{c}}$ & $71.45 \pm 1.75^{\mathrm{b}, \mathrm{c}}$ \\
Breast muscle ration (\%) & $22.33 \pm 2.55$ & $22.00 \pm 1.32$ & $22.11 \pm 2.45$ \\
Leg muscle ration (\%) & $19.04 \pm 1.70^{\mathrm{a}}$ & $18.50 \pm 2.62^{\mathrm{a}}$ & $20.00 \pm 1.93^{\mathrm{a}, \mathrm{c}}$ \\
Abdominal fat ration (\%) & $2.48 \pm 0.75$ & $2.32 \pm 0.78$ & $2.95 \pm 1.80^{\mathrm{b}, \mathrm{c}}$ \\
\hline
\end{tabular}

${ }^{a, b, c}$ Means within a row with different superscript are significantly different $(\mathrm{P}<0.05)$.

Table 5. Effects of phytase supplementation on internal organs of broilers.

\begin{tabular}{cccc}
\hline Attribute & Group A & Group B & Group C \\
\hline Heart $(\mathrm{g})$ & $13.40 \pm 3.16$ & $11.81 \pm 1.62$ & $12.44 \pm 2.11$ \\
Liver $(\mathrm{g})$ & $37.43 \pm 6.98^{\mathrm{a}}$ & $45.37 \pm 7.61^{\mathrm{b}}$ & $44.69 \pm 5.90^{\mathrm{b}}$ \\
Spleen $(\mathrm{g})$ & $2.13 \pm 0.52^{\mathrm{a}}$ & $2.56 \pm 0.62^{\mathrm{a}, \mathrm{c}}$ & $2.52 \pm 0.51^{\mathrm{a}, \mathrm{c}}$ \\
\hline
\end{tabular}

$\overline{\mathrm{a}, \mathrm{b}, \mathrm{c}}$ Means within a row with different superscript are significantly different $(\mathrm{P}<0.05)$. 
the microbial phytase was exploited on the broilers [15,17-19]. Some conclusions are in agreement with our results, and some researchers did not get the similar conclusions. Onyango et al. [20] reported that the diet supplemented phytase could improve the digestibility and feed conversion ration. Intestinal tract weight and length could be improved by adding the phytase to the feed. For example, the basal diet with phytase could improve the weight of cecum that was shown by Akyurek et al. [17].

\subsection{Effects of Phytase Addition on Serum Biochemical Parameters of Broilers}

Assay of biochemical indicator from blood serum is shown in Table 7. Compared with the control group broilers, the diets supplemented phytase increased $(\mathrm{P}<$ $0.05)$ the serum phosphorus, which was similar to results by Dendow et al. [21]. There was no significant difference $(\mathrm{P}>0.05)$ between group $\mathrm{C}$ and $\mathrm{D}$ broilers on serum phosphorus and it was possible that the addition of $0.02 \%$ phytase meted the needs of broilers. Serum Ca decreased with phytase increasing in diets. Serum Ca of group $\mathrm{C}$ and $\mathrm{D}$ broilers were higher than that of group $\mathrm{A}$ and $\mathrm{D}$ broilers $(\mathrm{P}<0.05)$. Regarding to the serum alkaline phosphatase, albumin, total protein, urea nitrogen and growth hormone of broilers receiving phytase, there was no significant difference $(\mathrm{P}>0.05)$ among treatment groups broilers (Table 7).

Peng Ying et al. [22] got the same results when they studied the effects of phytase on the performance and calcium and phosphorus metabolism of AA broilers by supplementing phytase in low $\mathrm{P}$ diets. Serum calcium decreased along with the used of serum phosphorus, and the high concentration of serum was not beneficial to the use of phytase.

\section{CONCLUSION}

According to the above analysis, the results of group $\mathrm{C}$ broilers were optimal. Consequently, the optimum adding levels of dietary phytase (enzyme activity for $5000 \mathrm{u} / \mathrm{g}$ ) was $0.02 \%$ which was made up by nutrient standard

Table 6. Effects of phytase supplementation on small intestine of broilers.

\begin{tabular}{ccccc}
\hline Attribute & Group A & Group B & Group C & Group D \\
\hline Duodenum length $(\mathrm{cm})$ & $26.50 \pm 2.36$ & $24.64 \pm 2.87$ & $26.50 \pm 2.92$ & $24.83 \pm 3.09$ \\
Jejunum length $(\mathrm{cm})$ & $63.06 \pm 8.09^{\mathrm{a}, \mathrm{b}}$ & $61.47 \pm 4.63^{\mathrm{a}}$ & $63.86 \pm 7.27^{\mathrm{a}, \mathrm{b}}$ & $66.94 \pm 5.70^{\mathrm{b}}$ \\
Ileum length $(\mathrm{cm})$ & $68.2 \pm 7.20$ & $61.79 \pm 7.09$ & $62.57 \pm 7.09$ & $66.11 \pm 5.75$ \\
Duodenum weight (g) & $5.93 \pm 0.90^{\mathrm{a}}$ & $6.52 \pm 1.36^{\mathrm{a}, \mathrm{c}}$ & $7.58 \pm 1.27^{\mathrm{b}, \mathrm{c}}$ & $6.32 \pm 1.29^{\mathrm{a}}$ \\
Jejunum weight (g) & $11.94 \pm 1.88^{\mathrm{a}}$ & $15.42 \pm 3.26^{\mathrm{b}}$ & $16.02 \pm 1.39^{\mathrm{b}}$ & $15.49 \pm 4.02^{\mathrm{b}}$ \\
Ileum weight $(\mathrm{g})$ & $12.24 \pm 1.64$ & $12.32 \pm 2.92$ & $13.78 \pm 2.24$ & $14.05 \pm 3.58$ \\
Cecum weight $(\mathrm{g})$ & $5.31 \pm 0.80$ & $5.00 \pm 1.06$ & $5.86 \pm 1.54$ & $5.78 \pm 1.35$ \\
Rectum weight $(\mathrm{g})$ & $2.03 \pm 0.49^{\mathrm{a}}$ & $2.36 \pm 0.42^{\mathrm{a}, \mathrm{c}}$ & $2.80 \pm 0.70^{\mathrm{b}, \mathrm{c}}$ & $2.74 \pm 0.33^{\mathrm{b}, \mathrm{c}}$
\end{tabular}

${ }_{\mathrm{a}, \mathrm{b}, \mathrm{c}}$ Means within a row with different superscript are significantly different $(\mathrm{P}<0.05)$.

Table 7. Effects of phytase supplementation on serum biochemical parameters of broilers.

\begin{tabular}{|c|c|c|c|c|}
\hline Attribute & Group A & Group B & Group C & Group D \\
\hline $\mathrm{Ca}(\mathrm{mmol} / \mathrm{L})$ & $2.96 \pm 0.53^{\mathrm{a}}$ & $2.80 \pm 0.52^{\mathrm{ab}}$ & $2.51 \pm 0.39^{\mathrm{b}}$ & $2.49 \pm 0.45^{\mathrm{b}}$ \\
\hline $\mathrm{P}(\mathrm{mmol} / \mathrm{L})$ & $1.19 \pm 0.44^{\mathrm{a}}$ & $1.63 \pm 0.46^{\mathrm{b}}$ & $1.95 \pm 0.29^{\mathrm{c}}$ & $2.20 \pm 0.46^{\mathrm{c}}$ \\
\hline ALP (U/L) & $2449.35 \pm 786.44$ & $2863.69 \pm 2151.20$ & $3345.69 \pm 2913.45$ & $2204.65 \pm 1161.02$ \\
\hline $\operatorname{ALB}(\mathrm{g} / \mathrm{L})$ & $18.69 \pm 1.82$ & $20.13 \pm 2.69$ & $19.53 \pm 2.16$ & $19.85 \pm 2.64$ \\
\hline $\mathrm{TP}(\mathrm{g} / \mathrm{L})$ & $31.34 \pm 5.87$ & $34.14 \pm 6.91$ & $33.08 \pm 5.26$ & $33.24 \pm 4.97$ \\
\hline BUN (mg/L) & $0.33 \pm 0.14$ & $0.41 \pm 0.12$ & $0.39 \pm 0.15$ & $0.41 \pm 0.13$ \\
\hline $\mathrm{GH}(\mathrm{ng} / \mathrm{ml})$ & $0.60 \pm 0.08$ & $0.60 \pm 0.06$ & $0.63 \pm 0.06$ & $0.63 \pm 0.11$ \\
\hline
\end{tabular}

ALP, alkaline phosphatase; ALB, albumin; TP, total protein; BUN, urea nitrogen; GH, growth hormone. ${ }^{\text {a,b,c }}$ Means within a row with different superscript are significantly different $(\mathrm{P}<0.05)$. 
of flesh chicks. From this research, proper phytase supplementation could increase the broilers growth; I recommend that the influence of phytase supplementation in meat quality of broilers could be investigated in further study.

\section{ACKNOWLEDGEMENTS}

This research was financially supported by the Priority Academic Program Development of Jiangsu Higher Education Institutions and the Support Project of Science and Technology of Jiangsu Province (NO. BE2011408), P. R. China.

\section{REFERENCES}

[1] Zhou, L.L. (2011) Selection and evaluation of phytase. Feed Industry Magazine, 32, 34-36.

[2] Nelson, T.S., Shieh, T.S. and Wodzinski, R.J. (1971) Effect of supplemental phytase on the utilization of phytase phosphorus by chicks. Journalof Nutrient, 101, 1289-1294.

[3] Peter, H.S. and Velmurugu, R. (2007) Microbial phytase in poultry nutrient. Animal Feed Science and Technology, 135, 1-41. doi:10.1016/j.anifeedsci.2006.06.010

[4] Simons, P.C.M., Versteegh, H.A.J. and Jongbloed, A.W. (1990) Improvement of phosphorus availability by microbial phytase in broilers and pigs. British Journal of Nutrition, 64, 525-540. doi:10.1079/BJN19900052

[5] Nagata, A.K., Rodrigues, P.B. and Alvarenga, R.R. (2011) Energy and protein levels in diets containing phytase for broilers from 22 to 42 days of ages: Performance and nutrient excretion. Revista Brasileira de Zootecnia, 40, 1718-1724. doi:10.1590/S1516-35982011000800014

[6] Lan, G.Q., Abdullah, N. and Jalaludin, S. (2002) Efficacy of supplementation of a phytase-producing bacterial culture on the performance and nutrient use of broiler chickens fed corn-soybean meal diets. Poultry Science, 81, 1522-1532.

[7] Sun, H.X., Gao, X.H. and Yang, L.L. (2011) High doses of microbial phytase affect growth performance and serum biochemical parameters in broilers chicks fed cornsoybean meal diets. Chinese Animal Husbandry and Veterinary, 38, 11-14.

[8] Qi, G.Z., Du, H.M. and Wang, J.J. (2010) Effect of phytase on growth performance and utilization of $\mathrm{Ca}$ and $\mathrm{P}$ in broilers. Acta Ecologiae Animalis Domastici, 31, 68-74.

[9] Chen, Q.H. (2005) Recerch of metabolism of animal phosphorus and endogenous phosphorus. China Feed Industry, 26, 40-43.

[10] Nagata, A.K., Rodrigues, P.B. and Alvarenga, R.R. (2011) Carcass characteristics of broilers at 42 days receiving diets with phytase in different energy and crude protein levels. Ciênc Agrotec Lavras, 35, 575-581. doi:10.1590/S1413-70542011000300020

[11] Rutherfurd, S.M., Chung, T.K. and Thomas, D.V. (2012) Effect of a novel phytase on growth performance, apparent metabolizable energy, and the availability of minerals and amino acids in a low-phosphorus corn-soybean meal diet for broilers. Poultry Science, 91, 1118-1127. doi:10.3382/ps.2011-01702

[12] Lelis, G.R., Albino, L.F.T. and Calderano, A.A. (2012) Diet supplementation with phytase on performance of broiler chickens. Revista Brasileira de Zootecnia-Brazilian Journal of Animal Science, 41, 929-933. doi:10.1590/S1516-35982012000400014

[13] Chisato, Y., Hirokazu, F. and Hisao, T. (2003) Effect of amino acid, enzyme mixture and phytase added to low protein and low phosphorus diet on growth performance and excretion of nitrogen and phosphorus in broilers. Journal Poultry Science, 40, 114-120. doi:10.2141/jpsa.40.114

[14] Yonemochi, C., Fujisaki, H. and Takagi, H. (2003) Effects of amino acid, enzyme mixture and phytase added to low protein and low phosphorus diet on performance and excretion of nitrogen and phosphorus in broilers. Journal of Poultry Science, 40, 114-120. doi:10.2141/jpsa.40.114

[15] Akyurek, H., Ozduven, M.L. and Okur, A.A. (2011) The effect of supplementing an organic acid blend and/or microbial phytase to a corn-soybean based diet fed to broiler chickens. African Journal of Agricultural Research, 6, 642-649.

[16] Attia, Y.A., Bohmer, B.M. and Dora, A.R. (2006) Responses of broiler chicks raised under constant relatively high ambient temperature to enzymes, amino acid supplementations, or a high-nutrient diet. Arch Geflugelk, 70, $80-91$.

[17] Akyurek, H., Agma, A. O. and Samli, H.E. (2009) Impacts of phytase and/or carbohydrases on performance, intestinal organs and bone development in broilers fed wheatbased diets containing different levels of phosphorus. Journal of Animal and Veterinary Advances, 8, 14321437.

[18] Smulikowska, S., Czerwinski, J. and Mieczkowska, A. (2010) Effect of an organic acid blend and phytase added to a rapeseed cake-containing diet on performance, intestinal morphology, caecal microflora activity and thyroid status of broiler chickens. Journal of Animal Physiology and Animal Nutrition, 94, 15-23. doi:10.1111/j.1439-0396.2008.00876.x

[19] Pirgozliev, V., Oduguwa, O. and Acamovic, T. (2007) Diets containing Escherichia coli-derived phytase on young chickens and turkeys: Effects on performance, metabolizable energy, endogenous secretions, and intestinal morphology. Poultry Science, 86, 705-713.

[20] Onyango, E.M., Asem, E.K. and Adeola, O. (2006) Dietary cholecalciferol and phosphorus influence intestinal mucosa phytase activity in broiler chicks. British Poultry Science, 47, 632-639. doi:10.1080/00071660600963651

[21] Dendow, D.M., Ravindran, V., Kornegay, E.T., Yi, Z. and Hulet, R.M. (1995) Improving phosphorus availability in soybean meal for broilers by supplemental phytase. Poultry Science, 74, 1831-1842. doi:10.3382/ps.0741831

[22] Ying, P., Wang, W. and Duan, W.G. (2011) Effects of KDN phytase on the performance and $\mathrm{Ca}$ and $\mathrm{P}$ metabolism of broilers fed low phosphorus diets. Journal of Food Agriculture \& Environment, 9, 348-352. 